\title{
頭頸部神経鞘腫症例の臨床的検討
}

\author{
高木 伸夫1)・福島 龍之2) ・ 村上 匡孝3)
}

\section{Pre-Operative Diagnosis of Neurinoma in the Head and Neck Region}

\author{
Nobuo Takagi \\ (Akashi City Hospital) \\ Tatsuyuki Fukushima \\ (Shakaihoken Kobe Chuo Hospital) \\ Masataka Murakami \\ (Kyoto Prefectural University of Medicine)
}

Neurinoma occasionally arises in the head and neck region and pre-operative diagnosis is difficult. In this study we analyzed 7 cases of neurinomas in the head and neck region, and we also discuss the problems of pre-operative diagnosis.

CT, MRI, ultrasonography and fine needle aspiration cytology (FNA) were performed and CT, MRI and ultrasonography produced compatible images of the neurinoma. However, FNA that was performed all cases were diagnosed as class I or II. We also report the diagnostic significace of CT, MRI, ultrasonography and FNA.

Key words : neurinoma, CT, MRI, ultrasonography, fine needle aspiration cytology (FNA)

\section{はじめに}

頭頸部領域において神経鞘腫の発生頻度は比較的まれ であるが，臨床においては時として遭遇する良性腫瘍と

して忘れてはならない疾患である。しかし，摘出すれば 容易に病理学的に診断できるものの, 術前に診断を確定 できないケースは決して珍しくない.今回われわれは 1996年から1998年までの 3 年間に経験した頭頸部神経䩗 腫 7 症例について, 診断上の問題点を中心に検討を加え て報告する。

\section{対 象}

対象は1996年 1 月より1998年12月の 3 年間に京都第一 赤十字病院耳鼻咽喉科を受診した頭頸部神経䩵腫 7 症例 である(表 1 ). 男性 4 例, 女性 3 例. 年齢は $23 \sim 63$ 歳(平
均值48.4歳)であった. 発生部位は頸部が 5 例，中〜上 咽頭が 1 例，食道が 1 例であった。検査は視診，触診， CT, MRI 打よび超音波断層検査に加兄, 穿刺吸引細胞 診(fine needle aspiration cytology, 以下 FNA と略す) を施行した。それぞれの術前検査や治療法について検討 を加えた。

\section{結 果}

(1) $\mathrm{CT}$

7 症例すべてにCT 検查を施行した(表 2 )。そのなか で軟口蓋に発症した神経鞘腫例(図 1 ) と頸部の神経鞘腫 例(図 2 )を示す.CT 検查に打ける腫瘍像は 7 症例すべ てに拉いて内部低吸收域であり，らち造影を施行した 4 症例のすべてに辺縁増強効果を認めた。

1）明石市立市民病院耳鼻咽喉科

2）社会保険神戸中央病院耳鼻咽喉科

3) 京都府立医科大学耳鼻咽喉科学教室 
表 1 神経鞘腫症例 ( 7 例)

\begin{tabular}{ccllll}
\hline \hline \multicolumn{2}{r}{ 年齢・性 } & \multicolumn{1}{c}{ 部 位 } & \multicolumn{1}{c}{ 主 } & 訴 \\
\hline 1. & 23 & 女 & 中 上咽頭 & 口腔内腫瘤 & 軟口蓋 \\
2. & 47 & 女 & 右頸部 & 頸部腫瘤 & 交感神経 \\
3. & 48 & 男 & 左頸部 & 頸部腫瘤 & 交感神経 \\
4. & 50 & 男 & 右頸部 & 頸部腫瘤 & 迷走神経 \\
5. & 54 & 男 & 右頸部 & 頸部腫瘤 & 迷走神経 \\
6. & 54 & 男 & 食道 & 前頸部腫瘤 & 食道筋層 \\
7. & 63 & 女 & 右頸部 & 頸部腫瘤・圧迫痛 & 腕神経叢
\end{tabular}

表 27 症例の CT ・ MRI - FNA 所見

\begin{tabular}{|c|c|c|c|c|}
\hline 症例 & CT 所見 & MRI 所 見 & FNA & $\begin{array}{c}\text { FNA } \\
\text { 施行回数 }\end{array}$ \\
\hline 1. 23女 & $\begin{array}{l}\text { 低吸収域 } \\
\text { 辺縁増強 }(+)\end{array}$ & 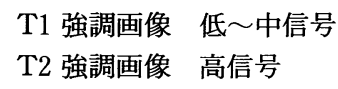 & 好中球・リンパ球（I） & 3 \\
\hline 2. 47女 & 低吸収域 & $\begin{array}{l}\mathrm{T} 1 \text { 強調画像 低信号 } \\
\mathrm{T} 2 \text { 強調画像 高信号 }\end{array}$ & 小リンパ球 & 1 \\
\hline 3. 48男 & $\begin{array}{l}\text { 低吸収域 } \\
\text { 辺縁増強 }(+)\end{array}$ & $(-)$ & 細胞成分 $(-)$ & 1 \\
\hline 4. 50 男 & 低吸収域 & $(-)$ & 好中球・赤血球 （I） & 2 \\
\hline 5. 54男 & 低吸収域 & $(-)$ & 好中球・組織球 （I） & 2 \\
\hline 6. 54 男 & $\begin{array}{l}\text { 低吸収域 } \\
\text { 辺緑増強 }(+)\end{array}$ & $(-)$ & 腺上皮・リンパ球（II） & 2 \\
\hline 7. 63女 & $\begin{array}{l}\text { 低吸収域 } \\
\text { 辺縁増強 }(+)\end{array}$ & $\begin{array}{l}\mathrm{T} 1 \text { 強調画像 低信号 } \\
\mathrm{T} 2 \text { 強調画像 高信号 }\end{array}$ & 神経䩪腫？ & 2 \\
\hline
\end{tabular}

(2) MRI

7 症例中 3 症例に施行（表 2 ）した. 軟口蓋に発症した 神経鞘腫例を図 3 に示す。腫瘍像は $\mathrm{T} 1$ 強調画像におい て低〜中信号, T2 強調画像に拉いて高信号であった. 他の 2 症例に执いては $\mathrm{T} 1$ 強調画像に拈いて低信号, T2 強調画像に执いて高信号であった。

（3）超音波断層検査

7 症例のすべてに施行した. 7 症例ともに腫瘍の境界 は明瞭であった。腫瘍内部については 3 症例は囊胞パ ターンを示し， 4 症例は内部不均一なパターンを示した.

\section{(4) FNA}

7 症例すべてに施行した. FNA には $21 \mathrm{G}$ 針を使用し た. 表 2 にFNA の結果と施行回数を示す. 7 症例中 6 症例では好中球, リンパ球, 赤血球のみで神経鞘腫の診 断は得られなかった。しかし, 症例 7 は紡錐形細胞が密 に配列する細胞集塊が少数認められ，興味深いことにこ の症例に拈いてはFNAを施行した際に手のしびれと痛
みを訴えて扣り，FNAの結果と併せて神経鞘腫と診断 することができた(図 4 ).

\section{考察}

神経鞘腫は神経周囲に存在するシュワン細胞に由来す る良性腫瘍であり，嗅神経と視神経以外のあらゆる脳神 経, 自律神経, 末梢神経から発症しらる1). 20〜 50歳に 多くみられ, 四肢, 頸部, 縦隔, 後腹膜, 先髄根部, 小 脳橋角部などが好発部位である. 肉眼的には薄い被膜を 有し，境界は明瞭で内部に囊胞を形成していることが多 い. 組織学的には定型的な棚状配列を示す Antoni A 型 と粘液腫状で小囊胞を取り囲んで変性を伴った細網線維 網を形成する Antoni B 型とがあり, 臨床的には両者が 混在していることが多いとされている2).

神経鞘腫は頸部に原発する良性腫瘍であるが，日常診 療で遭遇する頻度は必ずしも高くなく, 術前に細胞組織 学的に確定診断をつけておくことは意外に難しい. 実際 


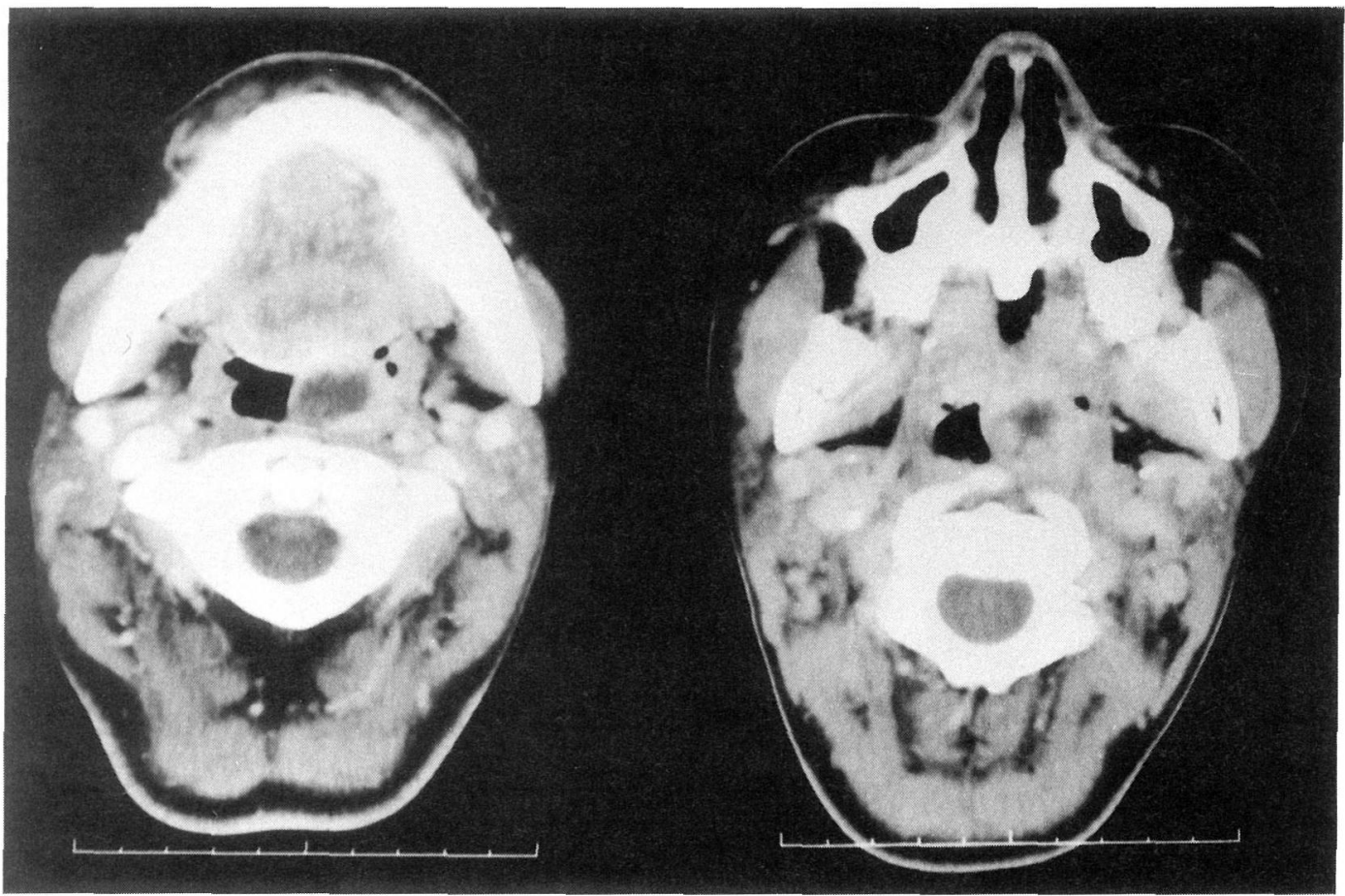

図 1 症例 1 のCT 所見 (左: 造影 CT, 右: 単純 CT)

内部が低吸収域, 辺縁増強効果のある腫瘍陰影を左中咽頭に認める.

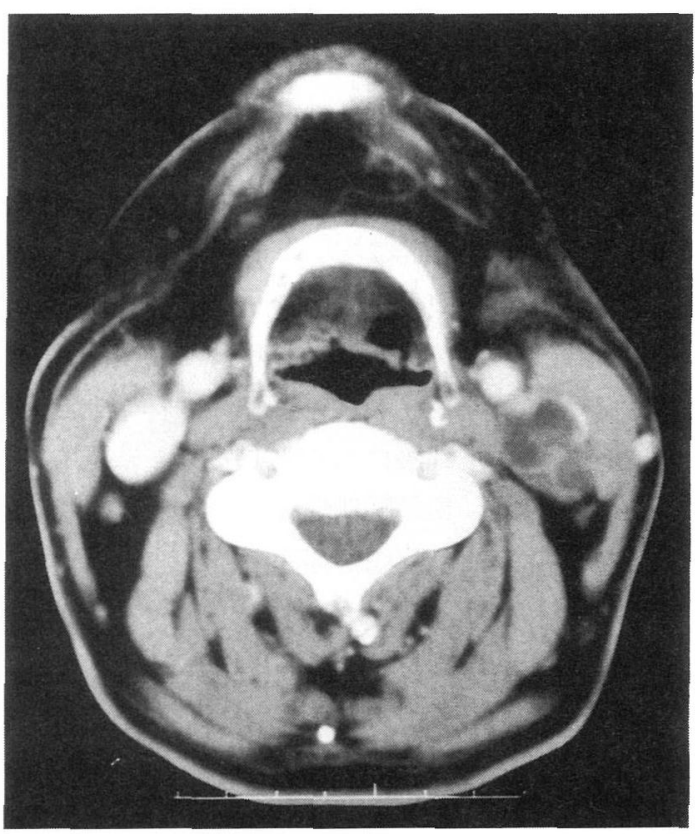

図 2 症例 3 の CT 所見

左上頸部に内部低吸収域, 辺縁増強効果のある腫瘍陰影 を認める。
われわれが呈示した 7 症例中, 術前に神経鞘腫の確定診 断を得られたのは 1 例のみであった。

一般的に頸部神経鞘腫と鑑別すべき疾患としては，悪 性腫瘍の頸部リンパ節転移, 悪性リンパ腫, 側頸虽胞, 頸動脈球腫瘍や時に軟口蓋や副咽頭間隙に発生する唾液 腺由来の多形腺腫などが挙げられる。各疾患の検査所見 の特徵を表 3 にま之め, 各検査別に検討を加兄てみる.

(1) $\mathrm{CT}$

神経鞘腫の CT 所見は, 境界が明暸で楕円形を呈し, 辺縁部が著明に増強され，内部は不均一な低吸収域を 伴った irregular peripheral enhancement , 腫瘍全体 が増強されている uniform enhancementがあるとされ ている3゙ 5)。去た，真鍋ら6) は神経鞘腫の $90 \%$ に造影 CT で辺縁増強効果があると報告している. 側頸囊胞に 扣いては増強効果がなく, 逆に頸動脈球腫瘍ではきわめ て強く造影されるので, これらとの鑑別は比較的容易と 思われる。それに対して, 多形腺腫や頸部リンパ節転移 は，時として神経鞘腫と同様の CT 所見を呈するので, CT 検查のみでは鑑別は困難である。 


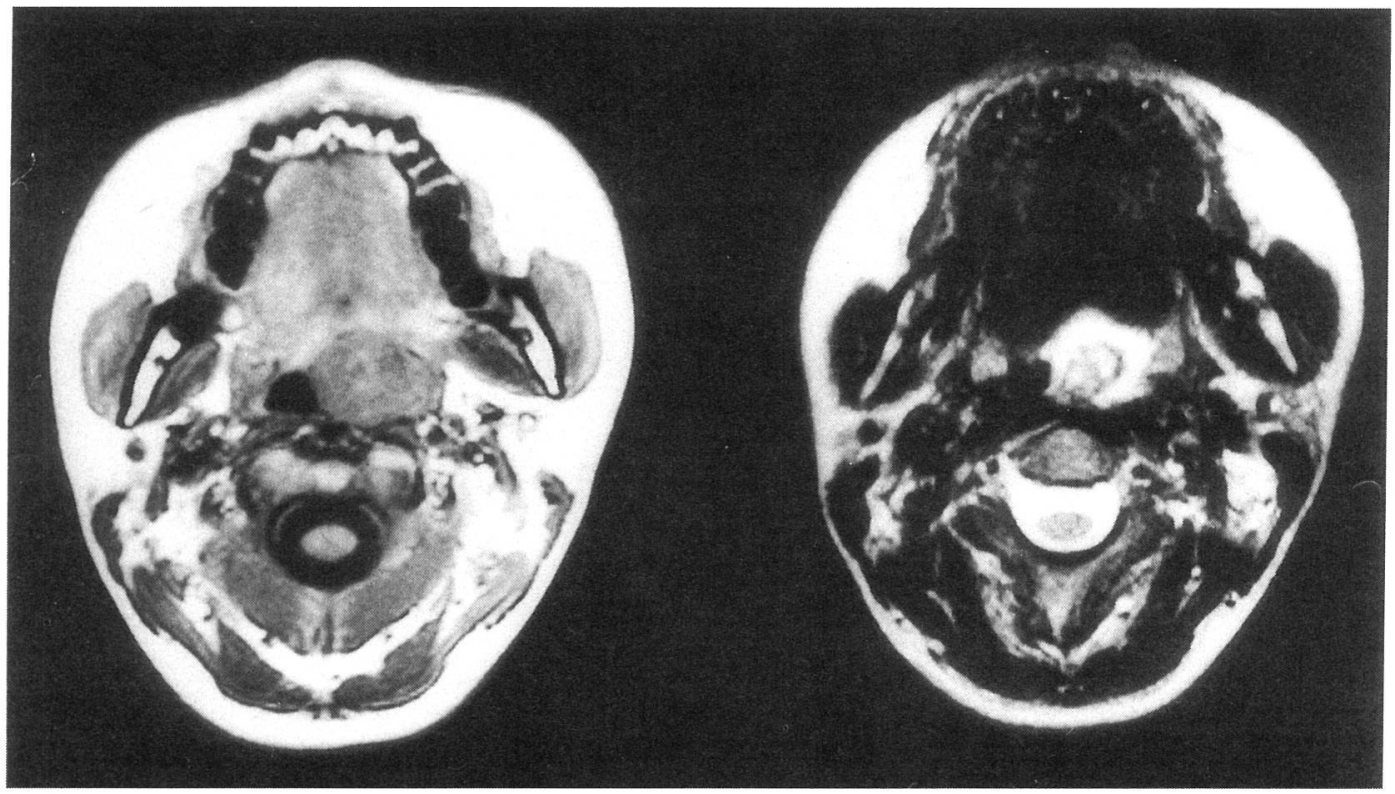

図 3 症例 1 の MRI 所見

$\mathrm{T} 1$ 強調画像にて低〜中信号 (左), T2 強調画像にて内部不均一な高信号 (右)の腫瘍陰影を認める.

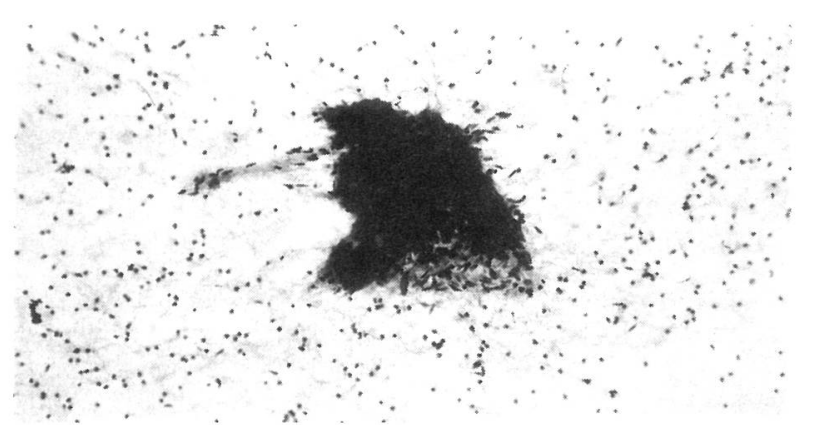

図 4 症例 7 の病理所見 $(\times 125)$

FNA による細胞塗抹標本で，紡鉡形細胞が密に配列す る細胞集塊が認められた。

(2) MRI

神経鞘腫の MRI 所見の報告例は少ないが，T1 強調 画像では筋組織とほ葟同様の比較的低信号, T2 強調画 像では高信号であり，内部の性状は T2 強調画像で不均 一，ガドリニウム造影 $\mathrm{T} 1$ 強調画像ではほ添均一に造影 されるといら報告7)とリング状に造影されるといら報告 がある ${ }^{8) \sim 10)}$ 。側頸囊胞では T1 強調画像にて低信号, T2 強調画像で高信号であるが，ガドリニウム造影にて造影 されるのは被膜のみであり, 頸動脈球腫瘍では T1, T2
強調画像とも低信号であるといら特徵があるので, 神経 鞘腫との鑑別は可能と考光る。しかし, 多形腺腫や頸部 リンパ節転移は, CT 検査と同様に MRI 陉いても神 経鞘腫と同様の所見を呈することがあるために，MRI 検査のみでは鑑別は困難であるといえる。

(3) 超音波断層検査

神経鞘腫の超音波所見は, 円形または楕円形で境界は 明瞭であり, 内部ェコーは均一, 不均一, 囊胞タイプと 組織を反映した各種のパターンを示す11)。また，神経鞘 腫が迷走神経由来であれば，内頸静脈之頸動脈の間に特 徽的な動・静脈解離現象が12), 腕神経由来の神経鞘腫で あれば由来神経が椎間腔に入るところまで確認できる13 と報告されている。頸動脈球腫瘍では拍動があり，内頸 動脈と外頸静脈の間に腫瘤が存在することから診断は容 易であると思われる。

(4) 穿刺吸引細胞診 (FNA)

FNA は腫瘍の質的診断方法として安全かつ有用な検 査方法である。しかし，FNAによってすべての疾患に 扣いて満足できる情報を得ることができるわけではなく， その一つが今回提示した神経鞘腫ではないかと考光てい る.

神経鞘腫の病理所見の特徴としては以下の諸点が挙げ゙ 
表 3 鑑別疾患

\begin{tabular}{|c|c|c|c|c|}
\hline & $\mathrm{CT}$ & MRI & 超＼cjkstart音 & FNA \\
\hline 神経鞘腫 & $\begin{array}{l}\text { 低吸収域 } \\
\text { 内部不均一 } \\
\text { 辺縁増強効果 + }\end{array}$ & $\begin{array}{l}\mathrm{T} 1 \text { 強調画像 低 中信号 } \\
\mathrm{T} 2 \text { 強調画像 中～高信号 } \\
\text { 増強効果 }+\end{array}$ & $\begin{array}{l}\text { 境界明瞭(均一・不均一・襄胞タイプ) } \\
\text { 動静脈解離現象 }\end{array}$ & 診断可? \\
\hline $\begin{array}{l}\text { リンパ節転移 } \\
\text { (悪性) }\end{array}$ & $\begin{array}{l}\text { 低吸収域 } \\
\text { 内部不均一 } \\
\text { 辺縁増強効果 + }\end{array}$ & $\begin{array}{l}\mathrm{T} 1 \text { 強調画像 低信号 } \\
\mathrm{T} 2 \text { 強調画像 高信号 } \\
\text { 増強効果 }+\end{array}$ & $\begin{array}{l}\text { 境界明瞭 } \\
\text { 点状も内部エコーが均一 }\end{array}$ & 診断可 \\
\hline 多形腺腫 & $\begin{array}{l}\text { 境界明瞭 } \\
\text { 低吸収域 } \\
\text { 辺縁増強効果 + }\end{array}$ & $\begin{array}{l}\mathrm{T} 1 \text { 強調画像 中信号 } \\
\mathrm{T} 2 \text { 強調画像 高信号 } \\
\text { 増強効果 }+\end{array}$ & $\begin{array}{l}\text { 境界明瞭 } \\
\text { 内部エコーは無エコー } \\
\text { 腫瘍後部エコー 増強 }\end{array}$ & 診断可 \\
\hline 側頸囊胞 & $\begin{array}{l}\text { 境界明瞭 } \\
\text { 低吸収域 } \\
\text { 辺緑増強効果 }\end{array}$ & $\begin{array}{l}\mathrm{T} 1 \text { 強調画像 低信号 } \\
\mathrm{T} 2 \text { 強調画像 高信号 } \\
\text { 増強効果 被膜のみ }\end{array}$ & $\begin{array}{l}\text { 境界明瞭 } \\
\text { 腫瘍後部エコー＼cjkstart増強 }\end{array}$ & 診断可 \\
\hline 頸動脈球腫瘍 & $\begin{array}{l}\text { 境界明瞭 } \\
\text { 増強効果 }\end{array}$ & $\begin{array}{l}\mathrm{T} 1 \text { 強調画像 低信号 } \\
\mathrm{T} 2 \text { 強調画像 低信号 } \\
\text { 増強効果 }+\end{array}$ & $\begin{array}{l}\text { 境界明瞭 } \quad \text { 拍動性 } \\
\text { 内部エコー 高エコー域 } \\
\text { 内頸動脈と外頸動脈の間に存在 }\end{array}$ & 施行しない方がよい \\
\hline
\end{tabular}

られる．1）細胞が束状，渦巻き状に配列すること．2） 境界不明瞭な細長い細胞質を有し，末端は毛髪状である こと. 3 ）細胞成分の豊富な束状配列を示す細胞群と紡 錐形細胞が比較的疎に結合して集団になってみられる部 分との 2 種類の細胞群が認められること．4）ときに棚 状配列がみられること．5）核は細長く，ガンマ一型を 呈し, 類円形や濃縮状のものが目立つ症例もある ${ }^{14)}$. 神 経原性腫瘍のように間質成分の多い硬い腫瘍では細胞間 が強く結合しているために細胞を採取できないことが多 いとされており15116)，21G 針での FNA では細胞を吸引 して採取することは困難であると思われる．実際，自験 例でも 7 例中 1 例しか腫瘍細胞を採取することができな かった．真鍋らのの報告によると FNA の結果はクラス I が $20 \%$ ，クラス II $608 \%$ ，クラス III $10 \%$ ， クラス $\mathrm{N}$ が $2 \%$ とNA では神経鞘腫の組織の診断がつきにくい などの否定的考えもある. しかし，多形腺腫や頸部リン

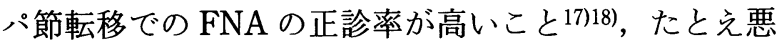
性腫瘍でる open biopsy に比べれば，FNAの方が侵襲 が少なく, 細胞播種の危険性が少ないことなどから考兄 ると，除外診断的に細胞診をとらえることも可能であり， 神経鞴腫の診断にあたって，CT，MRI や超音波断層検 査などの画像検査に加え, FNA の結果が他の疾患とし ての典型像がない場合は積極的に神経䩗腫の疑いを持つ 必要があると考兄る。

\section{まとめ}

1. 1996年から1998年までの 3 年間に経験した頭頸部 神経䩵腫の 7 症例について検討し, 報告した.

2. 7 症例の CT, MRI, 超音波および FNA 所見に ついて述べ，それぞれの検査の必要性と有用性について 検討した.

稿を終えるにあたり，ご指導を賜りました元京都第一赤十字 病院耳鼻咽啹科部長, 故安田範夫先生に深謝いたします。

な护，本論文の要旨は第 7 回日本頭頸部外科学会総会(東京) とてロ演した.

\section{参考文献}

1) 古川政樹, 山下耕太郎, 金子まどか, 他 : 頸部迷走神経よ り発症した神経鞅腫の 3 例. 日耳鼻 $91: 1256 \sim 1266,1988$.

2 ) 田中一化, 増田正純, 管家 稔, 他: 耳下腺内の顔面神経 鞘腫の 2 例. 耳喉頭頸 $71 ： 494 \sim 499,1999$.

3 ）鈴木光也, 広田圭治 : 悪性腪瘍の転移を思わせた頸部神経 原性腫場の 2 例. 耳啹頭頸 $66: 707 \sim 711,1994$.

4 ）松下智人, 竹田 寛, 田代敬彦, 他: 末梢型神経䩗腫の CT 像一病理組織像との対比一. 臨放 $35: 1391,1990$.

5) Chui M and Briant DR : CT evaluation of carotid sheath lesions. Br J Radiology 55 : 813 816, 1982.

6 ）真鍋 淳, 川口智義, 多湖光宗, 他 : 神経䩗腯 104 例の臨 床病理学的検討. 日癌治 $21: 147,1993$.

7 ）小檜山律, 菱川修司, 目黒浩昭, 他 : 鎖骨上窩アプローチ 
にて摘出できた上綎隔神経䩗腫の 1 例. 胸部外科 $50: 373$ $\sim 376,1997$.

8 ）岩本芳浩, 水川典彦, 関本達之, 他: 舌下神経麻痺で発症 した頸部迷走神経䩗腫の一例. 脳外 $45: 567 \sim 570,1993$.

9 ) 原口秀俊, 奥野秀次 : 頸部迷走神経鞘腫例. 耳鼻臨床 89 : $229 \sim 235,1987$.

10）志冨田由佳, 堀 洋二, 立花文寿, 他 : 副咽頭間隙腫瘍の 2 例. 耳鼻臨床 補61 : 217 224, 1994.

11）末永 通, 川浪 貢, 佐藤公輝, 他 : 頸部神経鞆腫の超音 波断層所見について.耳鼻 補34：677〜 683, 1988.

12）古川政樹：頸部の超音波検査法. JOHNS $9: 1665 \sim 1672$, 1993.

13）沼田 勉, 鈴木晴彦, 竹内洋介, 他 : 頸部疾患. 耳鼻咽喉 科領域に打ける超音波の情報的応用(金子敏郎編)．157〜 179頁, 文光堂, 東京, 1988.

14）藤井雅彦, 高橋正宜 : 中枢神経系腫瘍生検細胞診. 病理と
臨床 $3: 183 \sim 198,1985$.

15）佐々木健司，木村友紀，米原修司，他：富細胞型神経䩗腫 の穿刺吸引細胞診の 1 例. 日臨細胞広島会報 $19: 78 \sim 81$, 1998.

16）篠崎 登, 福永真治, 桜井健司, 他 : 穿刺吸引細胞訩が臨 床的に有用であった Von Recklinghausen 病に合併した悪 性神経䩪腫の 1 例. 外科診療 $29: 522 \sim 525,1994$.

17）永原國彦：頸部腫瘤の穿刺吸引細胞診. 耳喉頭頸 $64: 253$ $\sim 258,1992$.

18）林崎勝武，角南滋子：耳下腺多形腺腫の穿刺吸引細胞診. JOHNS $13: 51 \sim 56,1997$.

$\left(\begin{array}{l}\text { 原稿受付 : 平成 } 13 \text { 年 } 1 \text { 月 } 23 \text { 日 } \\ \text { 原稿採択 : 平成13年 } 5 \text { 月 } 9 \text { 日 } \\ \text { 別刷請求先 : 高木伸夫 } \\ \text { † } 673-8501 \text { 明石市鷹匠町1-33 } \\ \text { 明石市立市民病院耳鼻咽喉科 }\end{array}\right)$

